\title{
KONSTRUKSI SOSIAL BUDAYA MINANGKABAU ATAS PASAR
}

\author{
Damsar $^{1}$, Indrayani ${ }^{2}$ \\ Accepted Article:15 November 2016
}

\begin{abstract}
One of the ethnicities most commonly found as a trader, merchant, or other seller at markets all over Indonesia, starting from Sabang to Merauke, was the Minangkabau people. Minangkabau people engaged in various activities of commerce or trade all goods needs. In addition Minangkabau people known for their culinary efforts, in particularly Padang buffet. An interesting question about it is how the Minangkabau people can present almost in all markets that exist in the archipelago? How social and cultural structures of the Minangkabau society form the market? As well as how the economic behavior of the Minangkabau people in relation to the market? To answer the above questions done field research with qualitative approach. Research data obtained from various sources such as in-depth interviews on various market actors and indigenous experts Minangkabau, observation of reality and literature on sociocultural structures of the Minangkabau. The results showed that there is a qualitative relationship between socio-cultural structures of the Minangkabau, migration out ( merantau ) and markets. The market, culturally, is not separate from space Minangkabau people, because he was part of the prerequisites of the existence of a nagari. Migration out of the nagari or merantau is a cultural encouragement to become a useful person. One of the main roads traveled to become a useful person is to become entrepreneur, where the market is a place suitable for those options.
\end{abstract}

Keywords : Minangkabau, Migration, Social Construction of the Market, Entrepreneur

\begin{abstract}
Abstrak
Salah satu suku bangsa yang paling sering ditemukan di pasar sebagai pedagang atau penjual, di seluruh Indonesia dari Sabang sampau Merauke, adalah orang Minangkabau. Mereka terlibat dalam berbagai macam kegiatan bisnis atau perdagangan barang dan jasa yang diperlukan. Mereka dikenal dengan dalam usaha kuliner, khususnya restoran Padang. Pertanyaan menarik terkait fenomena di atas adalah bagaimana orang Minangkabau bisa hadir pada hampir semua pasar yang terdapat di Nusantara ini? Bagaimana struktur sosial dan budaya Minangkabau membentuk pasar? Dan bagaimana perilaku ekonomi orang Minangkabau dalam hubungannya dengan pasar? Untuk menjawab pertanyaan tersebut dilakukan penelitian lapangan dengan pendekatan kualitatif. Data dikumpulkan dari berbagai sumber seperti wawancara mendalam terhadap berbagai aktor pasar dan ahli adat Minangkabau, pengamatan lapangan, dan kepustakaan tentang struktur sosial budaya Minangkabau. Hasil penelitian menunjukkan bahwa terhadap hubungan kualitatif antara struktur sosial budaya Minangkabau, merantau dan pasar. Pasar, secara budaya, tidak terpisah dari ruang kehidupan orng Minangkabau; karena ia menjadi persyaratan bagi keberadaan suatu nagari. Sedangkan merantau merupakan suatu mekanisme sosial budaya Minangkabau untuk suatu pengakuan diri dan sosial dalam nagari melalui menjadi orang berguna. Salah satu jalan untuk menjadi orang berguna adalah menjadi entrepreneur, di mana pasar sebagai tempat yang cocok untuk meraihnya.
\end{abstract}

Kata Kunci: Minangkabau, Migrasi, Kontruksi Sosial Pasar, Wirausaha

\footnotetext{
${ }^{1}$ Penulis adalah Guru besar Sosiologi Ekonomi FISIP Universitas Andalas

${ }^{2}$ Penulis adalah Dosen Sumberdaya Manusia Pascasarjana Universitas Batam
} 


\section{A. PENDAHULUAN}

$\mathrm{P}$ asar merupakan salah satu institusi terpenting dalam ekonomi. Dinamika kehidupan ekonomi digerakkan oleh pasar. Lambat atau cepatnya pergerakan ekonomi tergantung pada lambat atau cepatnya pergerakan pasar. Pergerakan pasar tidak sama pada setiap masyarakat. Ada pasar yang pergerakannya cepat dan juga ada yang lambat. Lambat atau cepatnya pergerakan pasar tergantung salah satunya pada struktur sosial budaya masyarakat.

Pasar dalam masyarakat tertentu dikonstruksi sebagai wilayah yang kumuh, hina, jorok, atau kotor. Konstruksi seperti itu menyebabkan tidak semua kelompok atau lapisan masyarakat diperbolehkan untuk datang atau beraktivitas di pasar karena akan mencemari marwah status sosial mereka. Masyarakat mengonstruksi berbagai tuntunan budaya dalam bentuk pepatah-petitih, mamangan adat, aturan, dan larangan adat dalam hubungan dengan pasar. Konsekuensi logis dari hal tersebut adalah pasar tidak dikunjungi oleh semua anggota lapisan masyarakat. Sebaliknya hanya anggota kelompok masyarakat tertentu saja datang ke pasar.

Pada sisi lain, ada masyarakat yang menjadikan pasar bagian tidak terpisahkan dari struktur sosial budaya masyarakat, sehingga tidak terjadi eksklusi kelompok atau lapisan sosial tertentu terhadap pasar. Pada masyarakat seperti ini, pasar terbuka bagi seluruh lapisan dan kelompok dalam masyarakat. Tidak ada larangan adat atau hambatan budaya bagi suatu kelompok bila ingin masuk atau beraktivitas ke pasar

Salah satu etnik yang paling sering ditemukan sebagai pedagang, saudagar, atau penjual pada pasar-pasar di seluruh Indonesia, mulai dari Sabang sampai Merauke, adalah orang Minangkabau. Orang Minangkabau bergerak dalam berbagai kegiatan perniagaan atau perdagangan semua barang kebutuhan. Selain itu orang Minangkabau dikenal dengan usaha kulinernya, khususnya rumah makan Padang.

Pertanyaan yang menarik tentang hal ini adalah bagaimana orang Minangkabau bisa hadir hampir di semua pasar yang ada di nusantara ini? Bagaimana struktur sosial dan budaya masyarakat Minangkabau membentuk pasar? Serta bagaimana perilaku ekonomi orang Minangkabau dalam kaitannya dengan pasar?

Untuk menjawab pertanyaan tersebut di atas dilakukan penelitian lapangan dengan pendekatan kualitatif. Data penelitian diperoleh dari berbagai sumber seperti wawancara mendalam terhadap berbagai aktor pasar dan ahli adat Minangkabau, pengamatan terhadap realitas dan literatur tentang struktur sosial budaya Minangkabau.

\section{B. KERANGKA TEORITIS}

$\mathrm{D}$ alam bahasa latin, pasar dapat ditelusuri melalui akar dari kata "mercatus", yang bermakna berdagang atau tempat berdagang. Terdapat tiga makna yang berbeda di dalam pengertian tersebut: satu, pasar dalam artian secara fisik; dua, dimaksudkan sebagai tempat mengumpulkan; tiga, hak atau ketentuan yang legal tentang suatu pertemuan pada suatu market place. Pada abad ke-16, pengertian pasar, menurut Swedberg seperti yang dikutip Zusmelia (2007: 10), menemukan arti baru, yaitu "membeli dan menjual secara umum" dan "penjualan (interaksi pertukaran) yang dikontrol oleh demand dan supply". Kelihatannya definisi yang disebut terakhir inilah yang dirujuk oleh ilmu ekonomi sampai saat sekarang ini.

Dalam bukunya Penjaja dan Raja, Clifford Geertz (1973: 30-31) mencoba menelusuri pengertian pasar sebagai kata serapan dari bahasa Parsi, yaitu "bazar", lewat bahasa Arab bermakna suatu pranata ekonomi dan sekaligus cara hidup, suatu gaya umum dari kegiatan ekonomi yang mencapai segala aspek dari masyarakat, dan suatu dunia sosial-budaya yang lengkap dalam sendirinya. Jadi dalam pandangan Geertz, merupakan gejala gejala alami dan gejala kebudayaan, di mana keseluruhan dari kehidupan masyarakat pendukungnya dibentuk oleh pasar.

Dalam ekonomi klasik, seperti pandangan Adam Smith, melihat pasar sinonim dengan baik tempat jualan (marketplace) maupun sebagai suatu daerah geografis. Sedangkan ekonom yang datang kemudian, seperti Alfred Marshal melihat 
pasar sebagai suatu mekanisme dalam penciptaan harga.

Berbeda dengan pandangan ekonomi, sosiologi memandang pasar seba gai fenomena sosial yang kompleks dengan berbagai macam perangkatnya. Pasar dapat dipandang dari sudut yang beragam misalnya pasar merupakan suatu suatu struktur yang padat dengan jaringan sosial atau yang penuh dengan konflik dan persaingan. Pasar, dalam hal ini tempat pasar (market-place), dapat dilihat sebagai cermin dari kompleksitas sosial. Pasar, oleh sebab itu kata Mai dan Buchholt (1987: 2), mengandung berbagai informasi tentang barang yang diperdagangkan, tipe peda gang, perusahaan dan pembeli, juga organisasi sosial ekonomi perdagangan, harga pasar, kredit, strategi jual beli, etos kerja, kewiausahaan, serta aspek sosial dan komunikatif dari hari pasar.

\section{PASAR DAN STRUKTUR SOSIAL BUDAYA MINANGKABAU}

$\mathrm{S}$ ebelum mendiskusikan bagaimana kedudukan pasar dalam struktur sosial Minangkabau, terlebih dahulu didiskusikan bagaimana konsep pasar dalam masyarakat Minangkabau, sehingga pemahaman tentang pasar dalam struktur sosial budaya Minangkabau dapat lebih tajam.

\section{Konsep Emik Pasar}

Kalau ditelusuri konsep pasar, dalam konteks etimologis dan emik masyarakat Minangkabau, ternyata terdapat tiga konsep yang berbeda yaitu pasa, pakan, dan balai. Konsep pasa dalam masyarakat Minangkabau menunjuk pada suatu keadaan dan situasi keramaian yang berkelanjutan. Hal itu diterangkan oleh mamangan adat Minangkabau, yaitu "pasa jalan dek ditampuah, hapa kaji dek diulang" (pasar jalan karena ditempuh, hapal kaji karena diulang). Makna mamangan adat ini menegaskan bahwa jalan menjadi pasar karena dilalui secara berulang kali dan berkelanjutan. Adapun maksud pasar di sini, seperti maknanya bahasa Melayu dan Minangkabau, adalah sebagai jalan. Jadi, jalan menjadi pasar apabila terus menerus dilewati.

31 | P a g e
Sementara pakan (pekan) merujuk pada tempat pertemuan antara penjual dan pembeli yang diselenggarakan pada salah satu hari dalam sepekan. Oleh sebab itu pakan merupakan kegiatan pasar yang berlangsung dalam sekali seminggu pada hari tertentu dan dilaksanakan secara berulang dan tetap. Nama pekan, oleh karena itu, selalu dihubungkan dengan nama hari sepekan, yaitu pakan sinayan (pasar senen), pakan salasa (pasar selasa), paka rabaa (pasar rabu), pakan kamih (pasar kamis), pakan jumat (pasar jumat), pakan sabtu (pasar sabtu), dan pakan akad (pasar minggu).

Sedangkan balai (balai) merupakan tempat pertemuan para penghulu (pemimpin adat) untuk melakukan musyawarah dan mufakat dalam memutuskan sesuatu yang berkaitan dengan kebijakan publik atau kemaslahatan anak nagari. Pada saat pertemuan melakukan musyawarah dan mufakat di balai, maka para anak kemenakan (masyarakat nagari) dapat melihat dan mendengarkan kegiatan tersebut di luar balai. Karena balai merupakan tempat pertemuan, maka permintaan terhadap suatu barang dan jasa muncul. Ketika dahaga dan lapar muncul pada saat melihat dan mendengarkan musyawarah dan mufakat para pemimpin nagari, maka pada saat itulah dimungkinkan terjadinya penawaran terhadap barang dan jasa dalam kaitannya dengan pelepas dahaga dan lapar.

Bagaimana hubungan antara ketiga konsep tersebut sehingga ketiganya bisa dipahami sebagai tiga konsep menunjukkan satu kenyataan yaitu pasar dalam konteks etimologis dan emik? Pertemuan para penghulu (pemimpin adat) untuk melakukan musyawarah dan mufakat tentang sesuatu kaitannya dengan adat dilakukan di balai adat, sahingga daerah sekitar tersebut disebut balai. Sedangkan pertemuan itu sendiri dilakukan sekali sepekan, sesuai dengan hari dalam sepekan. Sehingga daerah pertemuan para penghulu (pemimpin adat) untuk melakukan musyawarah dan mufakat tersebut disebut juga pakan.

Selanjutnya, jalan menuju daerah pertemuan para penghulu (pemimpin adat) untuk melakukan musyawarah dan mufakat yang dilakukan sekali sepekan tersebut ditempuh terus menerus sehingga menjadi

Konstruksi Sosial Budaya Minangkabau Atas Pasar 
pasa. Oleh karena itu, pada umumnya nagari yang memiliki pasarnya sendiri, tidak berserikat dengan nagari lain, lokasi di mana tempat pasar berada adalah lokasi di mana terdapat balai.

Bagaimana pemahaman sosiologis terhadap ketiga konsep pasar tersebut? Dalam disertasinya tentang "Ketahanan (persistence) Pasar Nagari Minangkabau“, Zusmelia (2007: 135-145) melihat bahwa balai, pakan dan pasa merupakan suatu garis kontinum perkembangan tempat pasar (market place) dan mekanisme transaksi antara penjual dan pembeli, di mana balai dipandang sebagai bentuk yang sederhana sedangkan pasa sebagai bentuk yang paling komplit.

Fungsi pasar dalam nagari (balai, pakan dan pasa) terdiri dari fungsi layanan kultural (pertukaran sosial), layanan ekonomi (pertukaran ekonomi), dan layanan personal (pertukaran barang dan jasa).

Fungsi layanan kultural pada balai terdiri dari arena sosialisasi sosial-politik, kontrol sosial, pertukaran sosial, pembuatan kontrak tenurial, kontrak perkawinan, dan sumber gosip. Sementara pada pakan, kesemua fungsi yang terdapat pada balai dimiliki kecuali fungsi pertukaran sosial dan pembuatan kontrak tenurial dan kontrak perkawinan. Fungsi layanan kultural pada pasa lebih sedikit lagi dibandingkan dengan balai dan pakan, yaitu hanya berfungsi sebagai kontrol sosial dan sumber gosip.

Fungsi layanan ekonomi pada balai meliputi pertukaran barang dan jasa dan outlet promosi keterampilan (skill) dan hasil kerajinan. Sedangkan pada pakan dan pasa meliputi semua sub fungsi yang ada, yaitu pertukaran barang dan jasa, memperkuat kelompok (klientisasi) jaringan bisnis, informasi harga dan kualitas, dan outlet promosi keterampilan (skill) dan hasil kerajinan.

Fungsi layanan personal pada balai terdiri dari pemenuhan kebutuhan amenities dan hiburan serta membangun networking untuk kepentingan sosial ekonomi. Pada pasa juga memiliki dua fungsi yaitu pemenuhan kebutuhan amenities dan hiburan serta mencari peluang (opportunity) dan kesempatan bisnis. Sedangkan pakan memiliki kesemua fungsi yang ada.

\section{Pasar dalam Struktur Sosial Budaya Minangkabau}

Dalam struktur sosial budaya Minangkabau, pasar dinyatakan sebagai salah satu persyaratan terhadap keberadaan dari sebuah nagari, yaitu babalai bamusajik (mempunyai balai dan masjid). Balai, seperti telah dikemukakan di atas, dapat memiliki dua makna yaitu balai sebagai kerapatan adat dan sebagai (tempat) pasar. Kedua makna tersebut bisa muncul pada waktu yang bersamaan karena proses permintaan menciptakan penawaran, di mana kehadiran balai sebagai kerapatan adat memerlukan atau menciptakan kehadiran balai sebagai (tempat) pasar.

Pasar, oleh sebab itu, merupakan institusi penting dalam nagari, karena ia terkait dengan keberadaan nagari itu sendiri. Artinya nagari wajib memiliki pasar. Apabila suatu nagari tidak memiliki pasarnya sendiri, karena tidak mampu membangun suatu pasar, maka jalan keluar terhadap persyaratan keberadaan nagari adalah melakukan persekutuan dalam membangun pasar bersama dengan nagari lain yang berdekatan letaknya. Persekutuan nagari dalam mendirikan pasar menghasilkan pasar serikat. Pasar Baso di Kabupaten Agam, misalnya, merupakan pasar serikat dari persekutuan 4 nagari yaitu Nagari Tabek Panjang, Padang Tarok, Simarasok, dan Koto Tinggi.

Pasar nagari dalam sistem pemerintahan nagari sekarang ini merupakan suatu hal yang sangat penting. Karena salah satu sumber utama pendapatan nagari adalah berasal dari pengelolaan pasar. Pengelolaan pasar nagari dilakukan oleh Badan Perwakilan Pemilik Pasar, yang dibentuk oleh Kerapatan Adat Nagari (KAN) di bawah pengaturan pemerintahan nagari.

Pasar nagari merupakan cermin dari kompleksitas sosial. Pasar nagari tidak hanya mencakup tempat transaksi ekonomi antara penjual pembeli tetapi lebih dari itu, meliputi berbagai aspek persoalan kehidupan masyarakat nagari seperti tempat mencari jodoh, wisata, silaturahmi dengan teman atau kerabat yang lama tidak bersua, menikmati santapan enak, gudang informasi sosial budaya dan poltik lokal, dan sebagainya. 


\section{MERANTAU, KAPITAL SOSIAL, DAN PASAR}

$\mathrm{B}$ agaimana orang Minangkabau bisa hadir hampir di semua pasar yang ada di nusantara ini? Ada tiga variabel kunci yang berhubungan dalam menjawab pertanyaan ini, yaitu merantau, kapital social, dan pasar. Merantau merupakan suatu proses dan pola migrasi suku bangsa Minangkabau. Merantau, menurut Mochtar Naim (1984: 3), adalah institusi sosial pada masyarakat Minangkabau yang build in dalam budaya mereka. Merantau merupakan proses meninggalkan kampung halaman dengan kemauan sendiri untuk jangka waktu lama atau tidak, dengan tujuan mencari penghidupan menuntut ilmu atau mencari pengetahuan, biasanya dengan maksud kembali pulang.

Sosialisasi merantau telah terjadi pada saat seorang anak berusia sekitar 7 tahun. Pada usia tersebut seorang anak didorong untuk tidak tidur di rumah. la dituntun pergi tidur ke surau. Apabila ia tidak tidur di surau, ia akan diperolok oleh temanteman sebayanya (St. Iskandar, 1960; Radjab, 1950). Perpindahan tempat tidur sang anak dari rumah gadangnya ke surau, secara simbolik, dilihat sebagai proses perantauan pertama seorang anak ke dunia luar (surau). Para pemuda yang tidur di surau bukan sekedar tidur, tetapi lebih jauh dari itu, mereka dipersiapkan untuk menghadapi dunia luar yang lebih luas lagi, yaitu rantau.

Di suraulah mereka diperkenalkan gambaran tentang rantau oleh para senior mereka yang telah pernah merantau atau perantau yang sedang pulang kampung. Gambaran tentang rantau yang dipaparkan melalui penuturan para senior atau perantau yang sedang pulang kampung semuanya menarik hati dan memotivasi untuk segera pergi merantau (Radjab, 1950). Kesemua proses tersebut memperkuat ajaran adat bahwa. "karatau madang di hulu, babuah babungo balun, marantau bujang dahulu, di rumah baguno balun" (Karatau madang di hulu, berbuah berbunga belum, merantau bujang dahulu, di rumah berguna belum). Adapun makna fatwa adat tersebut adalah para pemuda diharapkan pergi merantau untuk menuntut ilmu atau mecari 33 | P a g e pengetahuan karena di rumah belum berguna.

Merantau, menurut Kato (1989), secara historis dapat dibagi atas tiga jenis, yaitu segmentasi kampung, merantau sirkuler, dan merantau Cino (Cina). Merantau dalam segmentasi kampung merupakan perpindahan untuk membentuk suatu pemukiman baru. Merantau jenis ini, pada umumnya, didorong oleh kekurangan tanah untuk bertani dan tekanan penduduk yang semakin meningkat jumlahnya. Perpindahan ini dilakukan oleh satu kelompok nasab ibu (matrilineal) atau sebagian kelompok keturunan, yang dipimpin oleh ketua kelompok keturunan. Perpindahan ini bersifat permanen. Adapun tipe pekerjaan yang dilakukan adalah kegiatan yang berhubungan dengan tanah dan pertanian.

Merantau sirkuler, dikenal juga dengan merantau pipit, merupakan proses migrasi ulang-alik yang dilakukan oleh pria, baik yang masih bujang maupun yang sudah kawin. Merantau jenis ini disebabkan oleh kekurangan tanah sebagai faktor pendorong dan terdapatnya beragam kesempatan yang ada di luar sebagai faktor penarik serta adanya ambisi pribadi. Adapun pekerjaan yang dilakukan adalah pekerjaan yang tidak terikat dengan tanah dan pertanian seperti pedagang, tukang, dan guru. Walaupun seorang pria telah menikah, namun istri dan anak-anaknya ditinggalkan di kampung. Oleh karena itu, migrasi ulang-alik rantau - kampung halaman dilakukan seiring dengan dengan kepulangan ke kampung halaman untuk melihat sanak saudara nasab ibunya serta anak-anak dan istrinya kemudian kembali ke rantau. Mobilitas geografis jenis ini, oleh sebab itu, tidak bersifat permanen.

Selanjutnya merantau Cino merupakan migrasi geografis permanen yang dilakukan oleh pada umumnya keluarga inti. Keluarga inti sebagai suatu unit pergi bersama merantau. Ketika seorang suami merantau, misalnya, setelah ia merasa bisa bertahan hidup di perantauan, hal yang pertama dilakukan adalah menjemput atau meminta istri dan anak-anaknya datang ke tempat dia merantau.

Bila ia adalah seorang bujang, ketika ia telah dipandang berhasil, hal Konstruksi Sosial Budaya Minangkabau Atas Pasar 
selanjutnya yang dilakukan adalah pulang kampung untuk menikah dan langsung membawa istrinya ke daerah di mana dia merantau. Migrasi jenis ini terkait dengan jarak yang jauh dari kampung halaman dan pada umumnya dengan tujuan kota-kota besar di Indonesia seperti Banda Aceh, Jakarta, Bogor, Depok, Bandung, Tangerang, Bekasi, Pekanbaru, Medan, Lampung, Makasar, dan lainnya. Faktor pendorong dan penarik dari merantau Cino sama dengan merantau sirkuler. Mobilitas merantau Cino yang bersifat permanen ini sebenarnya bukan tujuan mereka tetapi akibat dari perpindahan tersebut.

Proses merantau meninggalkan kampung halaman sebenarnya bukan merupakan keputusan pribadi, tetapi sering menjadi suatu keputusan dari kelompok, misalnya keluarga, ketetanggaan atau persahabatan. Hal ini dikarenakan keputusan merantau terkait dengan modal serta jaringan hubungan sosial budaya dan politik yang dimiliki. Pergi merantau meninggalkan kampung halaman diputuskan setelah paling tidak calon migran telah memiliki modal dasar awal berupa ongkos ditambah bekal untuk dapat hidup beberapa hari. Modal dasar awal ini berasal baik dari keluarga inti seperti orang tua, maupun keluarga luas seperti sanak saudara dan famili lainnya.

Modal dasar awal tersebut, terutama bekal hidup beberapa hari di kota, cenderung tidak diperlukan jika sang calon migran memiliki kapital sosial (social capita). Kapital sosial dimaksud di sini, merujuk Alejandro Portes (1995:12-13), merupakan kemampuan individu-individu untuk mengatur sumber-sumber langka berdasarkan keanggotaan mereka dalam jaringan atau struktur sosial yang lebih luas. Kemampuan menggerakkan jaringan hubungan sosial budaya dan politik yang dimiliki di daerah tujuan merantau sebagai keuntungan. Kepiawaian dalam menggunakan modal sosial dapat memberikan banyak peluang dan kesempatan. Ketika para pembentuk jaringan hubungan yang dimiliki tersebut memiliki rasa saling percaya maka salah satu pihak dapat saja memberikan modal uang dan barang kepada pihak lain.

Seorang migran yang baru datang ke kota, karena kemampuannya menggerakkan jaringan hubungan yang dimiliki sehingga menimbulkan kepercayaan pihak lain, dimungkinkan diberi kesempatan untuk mengelola suatu usaha atau modal uang dan barang untuk berusaha.

Dalam masyarakat Minangkabau jaringan hubungan tersebut dikonstruksi melalui sistem kekerabatan matrilineal yang bermula dari hubungan semande, seperut, senenek, seninik, sekaum dan sesuku. Semande menunjuk pada hubungan yang tercipta karena mereka dilahirkan dari seorang ibu yang sama. Seperut merupakan jaringan hubungan yang muncul karena sekelompok orang memiliki satu nenek yang sama. Senenek merujuk pada suatu jaringan hubungan yang timbul karena sekelompok orang mempunyai satu nenek buyut (gaek). Sementara seninik mencakup jaringan hubungan yang muncul dari kenyataan bahwa mereka berasal dari niniek yang sama. Sekaum adalah jaringan hubungan dari suku (marga/klan) yang sama dan dapat ditelusuri kaitan hubungan mereka. Sedangkan sesuku merupakan jaringan hubungan yang terbentuk karena memiliki satu suku (marga/klan) yang sama, namun kaitan hubungannya sudah sukar ditelusuri, misalnya sesama Caniago, namun berasal dari nagari yang berbeda.

Sistem itu dapat diperluas dengan hubungan horizontal lokalitas etnik seperti menjadi hubungan senagari, seluhak sampai seminangkabau. Senagari merupakan jaringan hubungan lokalitas yang mencakup jaringan hubungan dari beberapa jorong (korong) atau desa dalam suatu nagari. Sedangkan seluhak merupakan jaringan hubungan lokalitas yang meliputi satu daerah inti budaya Minangkabau.

Dalam konteks budaya Minangkabau, daerah inti meliputi luhak Tanah Datar, Luhak Agam, dan Luhak Limopuluh Koto. Dalam konteks Minangkabau kontemporer, konsep luhak telah digantikan oleh hubungan lokalitas administratif pemerintahan seperti kabupaten, misalnya sesama orang Kabupaten Pesisir Selatan. Sedangkan seminangkabau menunjuk pada hubungan lokalitas atau cakupan wilayah budaya Minangkabau. Pada konteks ini, makin kecil lingkaran semakin kohesif jaringan hubungan dan semakin tinggi pula kemungkinan untuk terciptanya saling percaya (lihat figur di bawah). 


\section{Figur Sistem Jaringan Hubungan Masyarakat Minangkabau}

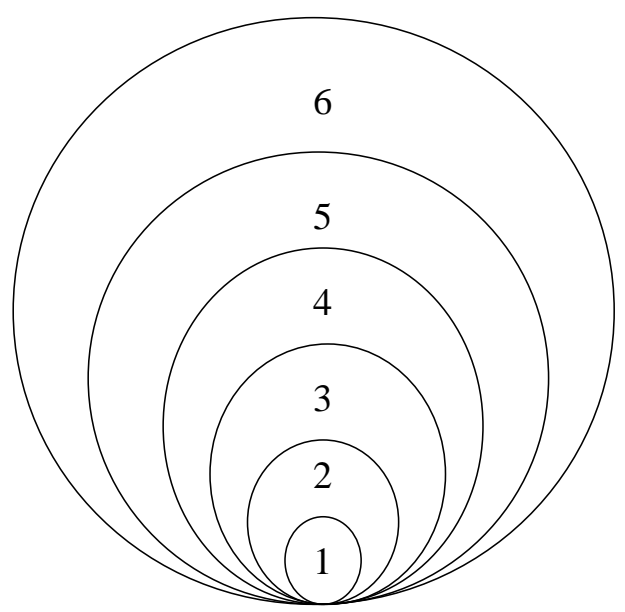

Catatan (1) semande (2) seperut (3) senenek (4) seninik (5) sekaum (6) sesuku

Apa yang diperbuat oleh para perantau pemula yang telah menautkan jaringan mereka pada sistem jaringan hubungan masyarakat Minangkabau? Pada umumnya para perantau yang baru datang dari desa tersebut melakukan proses pemagangan pada patron mereka di rantau, yaitu menjadi anak semang (anak buah) pada orang yang dianggap berhasil dalam jaringan hubungan tersebut.

Apa pula yang dilakukan perantau (pemula) bilamana mereka tidak menemukan jaringan hubungan masyarakat Minangkabau di perantauan? Memang tidak jarang para perantau (pemula) menemukan kenyataan bahwa daerah yang mereka datangi tidak ada orang Minangkabau, sehingga mereka harus menemukan atau membuat jaringan hubungan selain jaringan etnisitas Minangkabau. Mereka memetakan berbagai kemungkinan jaringan hubungan yang potensial untuk digunakan, yaitu antara lain jaringan hubungan sealmamater (satu sekolah atau kampus), seagama, sesumatera, atau sesama perantau. Bila mereka merantau ke daerah pedalaman Kalimantan atau Papua, misalnya, di mana mereka tidak menemukan orang Minangkabau, maka bisa saja mereka mencoba mendekatkan diri dalam membangun jaringan hubungan berbasiskan agama, almamater, kewilayahan (Sumatera), atau psikologi sosial (senasib- sepananggungan sesama perantau lainnya).

Adapun pekerjaan paling disukai oleh para perantau (pemula) adalah pekerjaan yang berhubungan dengan perdagangan dan keterampilan mandiri seperti penjahit. Kesemua pekerjaan tersebut tidak terlepas dari keterkaitannya dengan pasar. Dengan demikian pergi merantau bagi orang Minangkabau, pada dasarnya, adalah pergi ke pasar.

\section{E. PASAR DAN PERILAKU EKONOMI}

$\mathrm{B}$ agaimana perilaku ekonomi orang Minangkabau dalam kaitannya dengan pasar? Berikut beberapa perilaku ekonomi yang ditemukan pada orang Minangkabau dalam kaitannya dengan pasar.

\section{Etos Kerja Minang}

Apa yang menjadi penggerak orang untuk melakukan sesuatu ? Pertanyaan ini menyangkut dua hal yaitu berkait dengan konsep penggerak dan konsep sesuatu. Konsep penggerak dalam sosiologi bisa dilihat dengan beragam sudut pandang, misalnya dari Marxian dan Weberian. Sedangkan sesuatu di sini, dimaksud sebagai wirausaha. Dalam perspektif Marxian, keberhasilan dalam wirausaha digerakkan oleh kemampuan seseorang 
berkompetisi dalam merebut faktor-faktor produksi seperti tanah dan mesin-mesin produksi. Sedangkan dalam perspektif Weberian keberhasilan wirausaha dipenga ruhi oleh etos kerja yang dimiliki.

Etos kerja, seperti yang dikutip oleh Taufik Abdullah (1979:3) dari Geertz, merupakan "sikap yang mendasar terhadap diri dan dunia yang dipancarkan hidup". Etos adalah aspek evaluatif, yang bersifat menilai. Oleh karena itu dalam kaitannya dengan topik di atas diajukan pertanyaan: apakah kerja, dalam hal ini wirausaha, dipandang sebagai suatu keharusan hidup, atau sesuatu yang imperatif dari diri, atau sesuatu yang terikat pada identitas diri yang telah bersifat sakral? Identitas diri dalam hal ini adalah suatu yang telah digariskan oleh agama. Berkaitan dengan itu, juga perlu dipertanyakan, nilai etos kerja apa yang dikandung oleh budaya Minangkabau ? Apakah etos kerja yang dikandung tersebut berkorelasi positip terhadap suatu aktifitas ekonomi (wirausaha) ?

Max Weber, melalui The Protestant Ethic and the Spirit of Capitalism, memperlihatkan kemungkinan terdapatnya hubungan antara ajaran agama dan perilaku ekonomi. Orang Minangkabau tidak memisahkan hidupnya dengan agama dan adat. Orang Minangkabau tidak mau disebut sebagai orang yang tidak beradat juga tidak mau pula dikatakan sebagai orang kafir. Jadi antara adat dan agama merupakan suatu kesatuan, dalam hal ini kesatuan yang bersifat sintesis antara adat dan agama, yaitu suatu perpaduan yang saling menguatkan antara agama dan adat. Meskipun Weber beserta pengi kutnya seperti Geertz juga berusaha menjelaskan fenomena Islam namun tidak berhasil dalam memahami (verstehen) ajaran Islam tentang kerja dengan baik. Dalam ajaran Islam seluruh aktifitas kehidupan, termasuk kegiatan ekonomi, dipandang sebagai pengabdian kepada Tuhan seperti yang dianjurkan oleh QS 6:162, "Sholatku, ibadatku, hidupku, dan matiku hanyalah untuk Allah, Rab semesta alam". Pengabdian ini merupakan cara untuk memperoleh keberhasilan hidup di dunia dan di akhirat kelak. Pengabdian tidak hanya dalam bentuk ritual tetapi juga "kegiatan keduniaan" lainnya. Dengan demikian aktifitas religius tidak hanya ada dalam kegiatan ritual tetapi juga dalam kegiatan duniawi. Sedangkan kerja itu sendiri harus dilakukan dengan sebaik dan sekeras mungkin seperti yang diajarkan lewat hadist Rasullullah SAW, "beramallah kamu seolah-olah kamu mati esok pagi dan bekerjalah kamu seolah-olah kamu hidup selama-lamanya".

Selain itu, sebelum Weber mengemukakan teori organisasi dan birokrasi modern, Islam telah lama mengajarkan sikap berperhitungan dan prinsip akuntansi modern seperti yang diamanatkan oleh QS 2:282, "Hai orangorang yang beriman, apabila kamu bermu'amalah tidak secara tunai untuk waktu yang ditentukan, hendaklah kamu menuliskannya". Prinsip ini dilihat sebagai kewajiban umat Islam untuk melaksa nakannya. Seperti diketahui bahwa ilmuan Islamlah yang mengembangkan teori perhitungan modern melalui aljabar.

Selanjutnya Islam juga mewajibkan umatnya untuk berlaku sidik (jujur), amanah (acountability), tabligh (informasi benar), dan fathonah (cerdas) dalam setiap aktifitas hidupnya. Karena keempat nilai ini menjadi indikator nilai pembeda antara orang muslim dan orang munafiq. Keempat nilai ini merupakan landasan nilai utama bagi keberhasilan orang dalam semua aktifitas kehidupan, termasuk dalam aktivitas bisnis. Keberhasilan hubungan-hubungan bisnis atau ekonomi, baik tradisional maupun modern, dilandasi oleh keempat nilai tersebut. Hubungan bisnis tidak akan bisa berlanjut jika para aktor yang terlibat tidak memiliki kejujuran, misalnya.

Bagaimana pula kaitan antara adat dan etos kerja? Terdapat dua prinsip dasar perilaku ekonomi dalam falsafah adat Minangkabau, yaitu keseimbangan (equali brium) dan keadilan (justice). Prinsip keseimbangan (equalibrium) terdiri dari kesederhanaan (moderation), berhemat (parsimony) dan menjauhi pemborosan (extravagance). Dalam falsafah adat Minangkabau, nilai kesederhanaan (mode ration) : "balabiah ancak-ancak, bakurang sio-sio, Diagak mangko diagiah, dibaliak mangko dibalah, Bayang-bayang sapanjang badan:" ("Berlebihan berarti ria, Kalau kurang sia-sia, Dihitung dulu baru dibagi, Dibalik dulu baru dibelah, Bayang-bayang sepanjang badan"). Arti filosofis hidup sederhana dalam mamangan adat tersebut adalah kesederhanaan diletakkan dalam 
tatanan proporsional dengan memper hatikan beban jangan melebihi dari kemampuan. Kesederhanaan dalam tatanan proporsional menempatkan perencanaan dan hidup tidak konsumtif sebagai arahan dalam berperilaku.

Nilai berhemat (parsimony) diakui dalam falsafah adat Minangkabau, yang dipetik dalam pepatah-petitih adat berikut : "Bahimat sabalum habih, Sadiokan payuang sabalun hujan" ("Berhemat sebelum habis, Sediakan payung sebelum hujan"). Makna sikap hidup hemat dilakukan untuk menghindari "ketiadaan" atau kemelaratan di masa tua atau akan datang. Nilai tersebut juga menempatkan perencanaan masa depan sebagai tuntunan berperilaku.

Selanjutnya nilai menjauhi pembo rosan (extravagance), juga dikenal dalam falsafah adat Minangkabau berikut ini : "Waktu ado jan dimakan, Lah abiah baru dimakan" ("Ketika ada jangan dimakan, sudah bhabis baru dimakan"). Maksud fatwa ini adalah ketika tenaga masih kuat dan usia masih muda bekerjalah sekuat tenaga dan kumpulkan harta sebanyak mungkin, sedangkan pada waktu tua menikmati apa yang diperoleh ketika muda.

Prinsip keadilan (justice) terdiri dari nilai keadilan sosial, keadilan ekonomi dan keadilan distribusi pendapatan. Nilai keadilan sosial dikandung dalam fatwa adat berikut ini : "Gadang jan malendo, Panjang jan malindih, Cadiak jan manjua kawan, Nan tuo dihormati, nan ketek disayangi, samo gadang baok bakawan" ("Besar jangan melindas, Panjang jangan menindas, Cerdik jangan menjual kawan, Yang tua dihormati, Yang kecil disayangi, Sama besar bawa berkawan"). Ini dimaksudkan agar kita saling menghormati dan saling tenggang rasa di antara sesama. Perbedaan kemampuan, diingatkan, agar jangan menjadi penyebab seseorang menjadi penindas atau melakukan eksploitasi terhadap yang lain. Nilai keadilan ekonomi dikenal dalam falsafah adat Minangkabau. Nilai tersebut termuat dalam fatwa berikut ini : "Mandapek samo balabo, Kahilangan samo marugi, Maukue samo panjang, Mambilai samo laweh, Baragieh samo banyak, Manimbang samo barek" ("Mendapat sama berlaba, Kehilangan sama merugi, Mengukur sama panjang, Menyambung sama lebar, Berbagi sama banyak, 37|P a g e
Menimbang sama berat"). Prinsip profit and lost sharing diakui oleh fatwa adat di atas. Bagaimana prinsip tersebut dilaksanakan ? Menurut mamang adat dikatakan : "Gadang kayu gadang bahannyo, Ketek kayu ketek bahannyo" ("Besar kayu besar bahannya, kecil kayu kecil bahannya"). Makna mamangan adat ini adalah besar kecil suatu untung rugi didasarkan atas besar kecilnya sumbangan yang diberikan pada suatu usaha. Dengan kata lain, semakin besar kontribusi dalam perkongsian maka makin besar pula kemungkinan porsi meraih laba atau sebaliknya menuai kerugian.

Nilai keadilan distribusi pendapatan mendapat tempat dalam falsafah adat Minangkabau. Nilai tersebut terkandung dalam fatwa adat berikut : "Nan lamah makanan tueh, Nan condong makanan tungkek" ("Yang lemah perlu ditunjang, Yang miring perlu ditopang"). Arti fatwa ini adalah orang yang lemah (ekonomi) perlu ditolong. Siapa yang menolong ? Mamangan adat mengingatkan: "Adat badunsanak, dunsanak patahankan; Adat bakampuang, kampuang dipatahankan; Adat banagari, nagari patahankan; Adat babangso, bangso dipatahankan" ("Adat bersaudara, saudara dipertahankan; Adat berkampung, kampuang dipertahankan; Adat bernagari, nagari dipertahankan; Adat berbangsa, bangsa dipertahankan"). Jadi setiap orang Minangkabau yang memiliki kemampuan mempunyai kewajiban moral untuk membela sanak-saudara, kampung, nagari dan bangsa yang mengalami "kelemahan".

Kesemua nilai tersebut di atas menunjuk bagaimana adat Minangkabau memberikan tuntunan bagaimana berpe rilaku dalam aktivitas ekonomi. Tuntunan tersebut dapat pula menjadi identitas diri dari seorang Minangkabau.

\section{Kewirausahaan}

Berbicara tentang perdagangan maka orang tidak akan melupakan pembahasan kewirausahaan (entrepreneur ship). Seperti penelusuran Berger (1991: 1314) ekonom memandang kewirausahaan sebagai suatu akibat dari suatu konstelasi pada kondisi ekonomi tertentu, daripada sebagai suatu penyebab bagi pertumbuhan ekonomi. Berger melanjutkan bahwa para ekonom seperti Albert Hirschman dan Konstruksi Sosial Budaya Minangkabau Atas Pasar 
Alexander Gerschenkron cenderung mengabaikan arti dari kewirausahaan. Mereka menyatakan, jika kondisi ekonomi tidak cocok, maka kewirasusahaan tidak akan muncul dan masyarakat tetap akan stagnan. Ini berarti para ekonom melihat ekspresi sosial dan budaya (nilai, norma, kepercayaan, dan sebagainya) sebagai kekuatan eksternal.

Berbeda dengan para ekonom, sosiolog melihat kewirausahaan sebagai suatu variabel yang melekat erat dalam sumber-sumber sosial budaya seperti pola tindakan yang diorientasikan secara sosial, jaringan sosial dan modal sosial (Ligh dan Rosenstein, 1995: 166). Oleh sebab itu ketika membicarakan pola tindakan ekonomi yang diorientasikan secara sosial misalnya, saat itu perbincangan kewirausahaan telah dimulai. Aktifitas ekonomi yang dimotivasi oleh orientasi nilai baik bersumber dari agama maupun dari adat seperti amanah (accountability), tabligh (memberikan informasi yang benar), sidik (jujur), fathonah (cerdik dalam melihat sesuatu), keseder hanaan (moderation), berhemat (parsimony) dan menjauhi pemborosan (extravagance) merupakan panduan bagi orang Minang kabau dalam berbisnis.

Orientasi nilai yang demikian akan menghasilkan kepercayaan (trust) dalam interaksi dan transaksi bisnis. Kemampuan melakukan hal ini sehingga kepercayaan bisa diperoleh dipandang sebagai modal sosial. Kewiraswastaan merupakan produk dari suatu proses sosial budaya.

\section{Penutup}

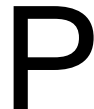
asar merupakan bagian yang tidak terlepas (build in) dan melekat (embedded) dalam struktur sosial Minangkabau, karena pasar adalah salah satu prasyarat dari keberadaan dari nagari itu sendiri. Pasar, oleh sebab itu, merupakan lokus ekspresif dan implementatif bukan hanya untuk aktivitas ekonomi tetapi juga bagi kegiatan adat masyarakat Minangkabau. Keberadaan orang Minang kabau di banyak pasar nusantara tidak terlepas dari budaya merantau yang muara utama dari aktivitasnya adalah pasar. Keberadaan perantau di pasar dirajut oleh kemampuan membangunan jejaring sosial dari berbagai basis seperti etnisitas, agama, almamater, kewilayahan, dan psikologis serta dorongan etos kerja dan semangat kewirausahaan yang berbasis adat dan agama. Pasar, oleh karena itu pula, merupakan tempat saluran etos kerja dan semangat kewirausahaan orang Minang kabau.

\section{Daftar Pustaka}

Berger, B. ed. (1991). The Culture of Entrepreneurship. San Fransisco: ICS Press

Berger, P. L. dan T. Luckmann (1990) Tafsir Sosial Atas Kenyataan, Risalah tentang Sosiologi Pengetahuan (terj.). Jakarta: LP3ES.

Mai, U. dan H. Buchholt (1987) Peasant Pedlars and Professional Traders. Singapore: ISEAS

Geertz, C. (1977) Penjaja dan Raja, Perubahan Sosial dan Modernisasi Ekonomi di Dua Kota Indonesia. Jakarta: Gramedia.

Kato, T (1989) Nasab Ibu dan Merantau. Kuala Lumpur : Dewan Bahasa dan Pustaka

Light, I dan C. Rosenstein (1995)"Expanding the Interaction Theory of Entreprenuership" dalam A. Portes (eds.), The Economic Sociology of Immigration. New York: Russel Sage Foundation

Naim, M. (1984) Merantau: Pola Migrasi Suku Minangkabau. Yogyakarta: Gadjah Mada University Press.

Portes, A. eds. (1995) The Economic of Immigration. New York: Russel Sage Foundation

St. Iskandar, N. (1960) Pengalaman Masa Kecil. Jakarta: Balai Pustaka.

Zusmelia (2005) Ketahanan (Persistence) Pasar Nagari di Minangkabau dalam Ekonomi Dunia: Kasus Pasar Kayu Manis (Cassiavera) di Minangkabau Provinsi Sumatera Barat. Proposal Disertasi Program Studi Sosiologi Pedesaan, Sekolah Pascasarjana IPB, Bogor. 